\title{
She will give birth immediately. Pregnancy and childbirth in medieval Hebrew medical texts produced in the Mediterranean West
}

\author{
Carmen Caballero Navas (*) \\ $\left(^{*}\right)$ Department of Semitic Studies, University of Granada. \\ carmenca@ugr.es
}

Dynamis

[0211-9536] 2014; 34 (2): 377-401

http://dx.doi.org/10.4321/S0211-95362014000200006
Fecha de recepción: 11 de marzo de 2013

Fecha de aceptación: 7 de febrero de 2014

SUMMARY: 1.-Introduction. 2.-The corpus of Hebrew medical literature and the management of pregnancy and childbirth. 3.-Dealing with conception and pregnancy 4.-The management of childbirth. 4.-Midwives and medical practice. 5.-Conclusion.

ABSTRACT: This essay approaches the medieval Hebrew literature on women's healthcare, with the aim of analysing notions and ideas regarding fertility, pregnancy and childbirth, as conveyed in the texts that form the corpus. Firstly, the work discusses the approach of written texts to pregnancy and childbirth as key elements in the explanation of women's health and the functioning of the female body. In this regard it also explores the role of this approach in the creation of meanings for both the female body and sexual difference. Secondly, it examines female management of pregnancy and childbirth as recorded in Hebrew medical literature. It pays attention to both the attitudes expressed by the authors, translators and copyists regarding female practice, as well as to instances and remedies derived from «local» traditions - that is, from women's experience - in the management of pregnancy and childbirth, also recorded in the texts. Finally, the paper explores how medical theories alien to, or in opposition to, Judaism were adopted or not and, at times, adapted to Jewish notions with the aim of eliminating tensions from the text, on the one hand, and providing Jewish practitioners with adequate training to retain their Christian clientele, on the other.

PALABRAS CLAVE: Embarazo, parto, textos hebreos, diferencia sexual, práctica médica de las mujeres.

KEY WORDS: Pregnancy, childbirth, hebrew texts, sexual difference, women's medical practice. 
«The birth can be natural, unnatural, or difficult. [...] The natural birth occurs most at the end of the seventh month or the ninth or the tenth. And the head should emerge first with the face downwards, and afterwards the neck, and after that the shoulder, and it should be that his hands will be alongside the body. The unnatural birth occurs when the legs emerge first, or the hands, or the sides. The difficult birth is when the foetus cannot emerge and tortures the mother and oppresses her - she will stand that anguish and that anxiety for a long time $[\ldots] »^{1}$.

\section{Introduction}

Thus begins Mi-qoshi ha-ledah (On difficulties of birth), a short Hebrew chapter on difficult birth, preserved in two manuscripts from the fourteenth and fifteenth centuries, respectively ${ }^{2}$. In scarcely two folios, the text elaborates on the causes and symptoms of difficult births and their management. But this is not the sole Hebrew medieval treatise to deal with this topic. While nearly half of the more than twenty Hebrew texts devoted to women's healthcare so far identified bear explicit reference in their titles to the domains of fertility, pregnancy and childbirth, all of them devote considerable portions (or even the whole) of their content to discussing these issues ${ }^{3}$.

In fact, pregnancy, the treatment of ailments assailing pregnant women, and childbirth and its management, feature as major issues in the medieval literature devoted to women's healthcare that circulated throughout the Mediterranean West in a wide variety of medieval languages. The Hebrew textual corpus dedicated to the care of women's health and disease, which circulated between the late twelfth century and the end of the Middle Ages, relied heavily upon the Latin medical tradition, as most of the texts were produced in the Christian territories of the Mediterranean West and

1. Barkai, Ron. A medieval Hebrew treatise on obstetrics. Medical History. 1989; 33: 96-119 (115).

2. Barkai, n. 1; Barkai, Ron. A history of Jewish gynaecological texts in the Middle Ages. Leiden: Brill; 1998, p. 5 and 58-59; MSS: London, British Library, Ms. Or. 10766, ff. 9r-9v. Paris, Bibliothèque Nationale, Ms. Heb. 1120, ff. 66r-67r. The text is accompanied in one of the manuscripts (Paris) by the 16 foetus-in-utero figures from Muscio's Gynaecia.

3. On the Hebrew corpus of literature on women's healthcare, see Barkai, n. 2, 1998; Caballero Navas, Carmen. The book of women's love and Jewish Medieval medical literature on women. Sefer ahavat nashim. London: Kegan Paul; 2004, p. 84-90; Caballero Navas, Carmen. Algunos «secretos de mujeres» revelados. El Šéar yašub y la recepción y transmisión del Trotula en hebreo. Miscelánea de Estudios Árabes y Hebraicos, Sección Hebreo. 2006; 55: 381-425. 
consisted mainly of translations into Hebrew from Latin. Besides the Latin influence, the Arabic medical tradition also had a bearing on the diagnoses, aetiology and therapeutics articulated in the texts. That said, more often than not, it reached the Hebrew medical corpus indirectly, as many of the Latin works rendered into Hebrew, or utilized and/or quoted by Jewish medical writers, were themselves translations from Arabic texts ${ }^{4}$.

The emergence of this type of literature in Hebrew is intimately connected to the emergence of the Hebrew medical library itself ${ }^{5}$, and coincides with two contemporary processes which were crucial in the development of medieval medicine: the so-called medicalization of medieval society, which resulted from the systematization of the need for healthcare ${ }^{6}$; and the professionalization of medicine - a process that endeavoured to gradually establish a legitimate system of healthcare provision and the conditions in which to control it. Both processes, and the need of Jewish physicians to gain access to regulated medical practice, determined the patterns for Jewish acquisition of medical knowledge, especially the consumption of medical literature - that is, the translation, production and dissemination of medical texts within Jewish communities - and prompted Jewish practitioners to accommodate their learning and practice to the new system of healthcare provision in a multicultural context.

In this scenario, the Hebrew body of texts on women's conditions was part of the attempt to guarantee that Jewish physicians had access to the newest trends in medicine to be found in the universities from which they had been excluded, even if they were unlikely to be intended for male

4. On the Arabic influence on Hebrew gynaecological literature, Barkai, n. 2, 1998, p. 41-44; Caballero Navas, Carmen. Un capítulo de mujeres. Transmisión y recepción de nociones sobre salud femenina en la producción textual hebrea durante la Edad Medieval. Miscelánea de Estudios Árabes y Hebraicos, Sección Hebreo. 2003; 52: 135-162.

5. Shatzmiller, Joseph. Jews, medicine and medieval society. Berkeley, Los Angeles and London: University of California Press; 1994; Caballero Navas, Carmen. Medicine among medieval Jews: The science, the art, and the practice. In: Freudenthal, Gad, ed. Science in medieval Jewish cultures. Cambridge: Cambridge University Press; 2011, p. 320-342, on p. 329-337; and Freudenthal, Gad. Arav and Edom as cultural resources for medieval Judaism: Contrasting attitudes toward Arabic and Latin learning in the Midi and in Italy. In Caballero Navas, Carmen; Alfonso, Esperanza, eds. Late medieval Jewish identities. Iberian and beyond. New York: Palgrave; 2010, p.123-156.

6. Shatzmiller, n. 5; McVaugh, Michael. Medicine before the Plague. Practitioners and their patients in the Crown of Aragon: 1285-1345. Cambridge and New York: Cambridge University Press; 1993. 
medical practice. ${ }^{7}$ By the same token, all these texts were mostly authored by men, and addressed to men ${ }^{8}$. They are witness, in fact, to the progressive exclusion of women from the legitimate practice of medicine. However, at the same time, the texts also record instances of women's experience and of acknowledgement of women's expertise in the management of childbirth.

The aim of the present essay is then threefold. On the one hand, it discusses the approach of written texts - that is, learned male physiciansto pregnancy and childbirth as key elements in the explanation of women's health and the functioning of the female body. In this regard it also explores the role of this approach in the creation of meanings for both the female body and sexual difference.

It also examines female management of pregnancy and childbirth as recorded in Hebrew medical literature. It pays attention to both the attitudes expressed by the authors, translators and copyists regarding female practice, as well as to instances and remedies derived from «local» traditions -that is, from women's experience- in the management of pregnancy and childbirth, also recorded in the texts. With the aim of shedding light on women's involvement in this sphere of care, some instances have been compared with examples from other sources, taking also into consideration the cross-religious character that attention to childbirth often involved in a multicultural society.

Finally, the paper explores the attitudes of Jewish medical authors, translators and copyists towards theories and practices alien to, or in opposition to, Judaism.

\section{The corpus of Hebrew medical literature and the management of pregnancy and childbirth}

As mentioned earlier, the genre of medical Hebrew literature on gynaecology was launched at the end of the twelfth century, following the Latin gynaecological tradition. The foundation on which it was built was laid

7. On the interest of male physicians in gynaecology, see Green, Monica. Making women's medicine masculine. The rise of male authority in pre-modern gynaecology. Oxford: Oxford University Press; 2008.

8. Most texts are written in the masculine. Green, Monica. The Development of the Trotula. Revue d'Historie des Textes. 1996; 26: 119-203, p. 139; Caballero Navas, n. 3, 2004, p. 80. 
out during the last years of that century (1197-1199), by the Provençal translator Do'eg ha-Edomi, who rendered from Latin into Hebrew three gynaecological texts as part of his impressive project of translating a total of 24 medical works ${ }^{9}$. Two of the gynaecological works he translated derived from Latin adaptations of the Gynaecology by Soranus of Ephesus. One of them, based on the fifth-sixth-century Latin version by Muscio, was entitled by its translator as Sefer ha-toledet or Book of Generation ${ }^{10}$.

Many other Hebrew texts produced from this century onwards contained in their titles words belonging to the domains of fertility, conception, pregnancy, childbirth, and the like. One such example is the Castilian treatise Zikhron ha-holayim ha-howim be-khlei ha-herayon or A record of the diseases occurring in the genital members ${ }^{11}$. This treatise, written at around the end of the twelfth and beginning of the thirteenth century by a thus far unknown author, devoted one of its two parts to diseases specifically female in nature. This part includes a section covering the difficulties of childbirth, in which the author enumerates diverse causes that may encumber the process, and offers guidelines as to how the midwife should be instructed -allegedly by the physician - to help the woman during labour and facilitate delivery. Slightly later, the Terufot le-herayon ha-niqra' Magen ha-rosh or Medicaments for pregnancy, called «The head's shield»-a treatise attributed to Rabbi Sheshet, leader of the Barcelona Jewish Community during the twelfth-thirteenth century - began to circulate. The book was written in Arabic and subsequently translated into Hebrew by Jehudah al-Harizi ${ }^{12}$. During the thirteenth century, two other treatises were also labelled in a similar fashion: Liqutei Rabbenu Mosheh be-inyanei weset we-herayon, or Maimonides' Compilation on menstruation and pregnancy, which is, in reality, Chapter 16 of Maimonides' Medical aphorisms that, apparently, shortly after its translation from Arabic into Hebrew, began to circulate independently ${ }^{13}$; and Hippocrates' Book on pregnancy and the womb, which is

9. Barkai, n. 2, 1998, p. 20-34; Freudenthal, n.5, p. 144-147.

10. Barkai, Ron. Les infortunes de Dinah, ou la gynécologie juive au Moyen Âge. Paris: Cerf; 1991.

11. Barkai, n. 2, 1998, p. 109-144 (edition and Hebrew translation). The Hebrew title alludes explicitly to «pregnancy», a term which has disappeared in the English translation.

12. Barkai, n. 2, 1998, p. 192-211.

13. As yet unpublished, the treatise has been preserved in two manuscript copies, the editing and translation of which I am currently working on. See Caballero Navas, Carmen. Maimonides' contribution to women's health care and his influence on the Hebrew gynaecological corpus. In: Fraenkel, Carlos, ed. Traditions of Maimonideanism. Leiden: Brill; 2009, p. 33-50. 
a translation from an Arabic version of De superfetatione ${ }^{14}$. There are three texts from the fourteenth century that also make reference to pregnancy or childbirth in their titles: Ha-ma'amar be-toladah niqra' sod ha'ibur or The treatise on procreation called «Secret of conception», a fourteenth-century tract that deals with the diagnosis and treatment of sterility in men and women $^{15}$; the aforementioned On difficulties of birth ${ }^{16}$; and the short treatise Merqahat mo'il le-qabel ha-herayon be-shem ha-rofe' Me. Vidal Debourian or Electuary useful for Conception, attributed to the physician Master Vidal de Bourian ${ }^{17}$. Moreover, there exist a Sha'ar be-sibat 'aqarut ha-nashim or Chapter on the cause of sterility of women, written between the fourteenth and fifteenth century ${ }^{18}$, and the fragment Terufot le-ishah she-tiqanes leherayon or Medicaments for a woman to get pregnant (1410) ${ }^{19}$.

Apart from these treatises, all other Hebrew texts belonging to this sphere of medical literature discuss these same issues albeit to different extents, for example the Book of women's love, a thirteenth-century anonymous compilation organized in three sections. The third section, dealing with what the author labels as «women's issues», offers a series of treatments including methods for ascertaining whether a woman is fertile, medicines to get pregnant and to avoid miscarriage, procedures to facilitate childbirth and extract the placenta, remedies to relieve post-partum pains and to promote the flow of breast milk, and also methods for preventing pregnancy and provoking abortion ${ }^{20}$.

We also have Sha'ar ha-nashim or Chapter on women, an anonymous fourteenth-fifteenth-century treatise, whose contents are identified by its author as «women's matters». Nearly half of these contents are devoted to dealing with issues such as the swelling of a woman's belly after birth, methods to facilitate and speed up delivery, procedures to help expel the foetus (dead or alive), remedies against post-partum pains, treatments to facilitate conception, and procedures and medicaments to expel the dead

14. Zonta, Mauro. A Hebrew translation of Hippocrates' De superfoetatione: Historical Introduction and Critical Edition. Aleph. 2003, 3: 97-143.

15. Barkai, n. 2, 1998, p. 212-222 (edition and Hebrew translation).

16. Barkai, n. 1.

17. Unpublished. Quoted by Barkai, n. 2, 1998, p. 82.

18. Unpublished. Quoted by Barkai, n. 2, 1998, p. 5.

19. It has been preserved in one single manuscript copy, yet unpublished. Cambridge, University Library, MS 33, 4, fol. $111 \mathrm{v}$.

20. Caballero Navas, n. 3, 2004, p. 118-176. 
foetus. It also enumerates the causes that impede conception, such as abscesses in the womb ${ }^{21}$.

All the treatises hitherto identified are, in the main, practical texts, written anonymously, generally arranged as a collection of recipes with scant theoretical input, which offer therapeutic procedures and remedies to alleviate women's ailments, but also deal with general healthcare and cosmetics $^{22}$.

Despite their practical content and design, the texts articulate ideas and notions that are embedded in contemporary Graeco-Arabic medical knowledge, and reflect an approach largely based on the Galenic humoral system. That is, women's physiology is explained according to a coherent framework that assumes health to depend on the balance of the four humours, each one associated with two of the four primary qualities. In accordance with this system, a model for the healthy female body is construed, and, concomitantly, cultural perceptions and expectations of normality are conveyed, together with their opposite notions of abnormality and illness. As I have discussed elsewhere, in both ancient and medieval medical traditions the specific features ascribed to women not only distinguished them from men but helped to assign different social roles to both sexes. That is, medical theories partook of the cultural construction of gender, and imbued health and disease with gender-specific meanings. From the medical point of view, men were simply men, while women were defined as virgins, pregnant, barren, widows, and so on ${ }^{23}$. Hence, medical authors' treatment of fertility, pregnancy, and childbirth contributed to the creation of meanings for the female body and, hence, for sexual difference ${ }^{24}$.

However, this is not the only perceptible approach in this particular genre of medical literature. Despite the difficulty of perceiving human activities behind written texts, traces of actual practice often permeate the recommendations aimed at facilitating conception, caring for pregnant women, and managing childbirth, which were mostly in the hands of women

\footnotetext{
21. Caballero Navas, n. 4, 2003.

22. See n. 3.

23. Caballero Navas, Carmen. Maimonides and his practice of gynaecology. In: Collins, Kenneth; Kottek, Samuel; Rosner, Fred, eds. Moses Maimonides and his practice of medicine. Haifa: Maimonides Research Institute; 2012, p. 61-84, p. 66.

24. Moral de Calatrava, Paloma. La mujer imaginada. La construcción cultural del cuerpo femenino en la Edad Media. Murcia: Nausícaä; 2008, p. 72-97.
} 
until the end of the Middle Ages ${ }^{25}$. Alongside Graeco-Arabic medical notions, remedies derived from actual practice and the lifelong experience of women in the management of pregnancy and childbirth are also recorded in Hebrew medical literature.

In fact, medical texts sometimes elaborate on midwifery procedures during delivery. For example, in aphorism 29 of Maimonides' Compilation on menstruation and pregnancy it is explained that midwives do not sit women on the birthing stool during labour pains, but rather only after they have explored the woman manually and found the opening of the womb to be dilated ${ }^{26}$. The author of the Castilian treatise $A$ record of the diseases occurring in the genital members, uses the term «midwife» (meyaledet) when he specifies that, at the physician's request, she must be the one who helps the woman to perform the movements that facilitate the expulsion of the foetus in the case of arrested labour:

"If the cause [for retention of the foetus] is fatness, you should order the midwife to lay the woman on her back, and put her knees under the woman's hips, to sit on her and to anoint her womb with moistening things such as fat and oil, hen fat or goose fat oil, and make her sneeze by putting soft wood or twisted papyrus in her nose» ${ }^{27}$.

Interestingly, it seems that the function of midwives is to manipulate other women's bodies but, generally, under the instructions of the physician. This way of presenting their role as auxiliary or subordinate to that of the physician is part of a rhetoric that endeavours to draw the boundaries of legitimate practice and to establish a division of the healthcare workforce. While learned physicians held the monopoly on theoretical knowledge,

25. Cabré i Pairet, Montserrat. «Como una madre, como una hija»: las mujeres y los cuidados de la salud en la Baja Edad Media. In: Morant, Isabel, dir. Historia de las mujeres en España y América Latina. De la Prehistoria a la Edad Media. Madrid: Cátedra; 2005, p. 637-657, p. 640.

26. Maimonides. Pirqe Mosheh ba-refuah. Muntner, Suessman, ed. Vol. 2 of Ketavim refuiyim [leRabenu Mosheh ben Maimon]. Jerusalem: Mosad Harav Kook; 1982, p. 209 and 211, respectively; Steinberg, W.; Muntner, Suessman. Maimonides' views on gynecology and obstetrics: English translation of Chapter Sixteen of his treatise «Pirke Moshe» (Medical Aphorisms). American Journal of Obstetrics and Gynecology. 1965; 91: 443-448, on p. 447. Maimonides also mentions the midwife's birthing stool in the Mishneh Torah, Kelim (Utensils) 25:2, as an implement susceptible to ritual uncleanliness.

27. Barkai, n. 2, 1998, p. 117 and 136, in Hebrew and English, respectively. 
women, such as the midwives and other women mentioned in medical texts, were 'only' responsible for manipulating the female body.

The extent of male physicians' interest in differentiating their role from that of women is emphasised by Do'eg ha-Edomi, the translator of Sefer ha-toledet, who chose to transform the original text by presenting it as a dialogue between the Biblical patriarch Jacob and his daughter Dinah. Throughout the treatise, Dinah addresses her father with many questions on women's conditions related to their life cycle. Jacob, presented as an expert on these issues, answers the questions of his distressed daughter ${ }^{28}$. It would seem Doeg's aim was at least twofold: to "Judaize» the text by attributing the dialogue to two Biblical characters, and to strip women of authority and autonomy in this sphere of medical care.

Regarding the «Judaization» of the treatise, the translator does not only achieve this by resorting to Biblical figures and references, but also by eliminating from it some of Soranus' (and Muscio's) most disturbing concepts from a Jewish point of view - for example, the notion that pregnancy may be harmful for women, which contradicts sharply the commandment «Be fruitful, and multiply» (Gen. 1, 28) ${ }^{29}$. Confronted with this clash of ideas, Do'eg chooses not to translate the paragraph into Hebrew ${ }^{30}$.

As for Do'eg's effort to strip women of authority, the acknowledgement of the practice of some of these women has sometimes reached us, ironically, through the criticism of their learned contemporaries, who were at pains to demonstrate that these practitioners were not qualified and put the health of their many patients at risk. They also accused women, especially older women, of lacking scientific knowledge and, thus, of sustaining their practice solely on the basis of experience. Maimonides, for example, criticized older women, and unqualified practitioners in general, to that effect ${ }^{31}$. In a similar manner, the unknown author of the medical encyclopaedia Sefer ha-yosher, written in Provence in the final decades of the thirteenth

\footnotetext{
28. Barkai, n. 10.

29. For the quotation of biblical verses I have followed King James Bible.

30. For the Latin, see Radicci, Rino. La «Gynaecia» di Mucione: Manuale per le ostetriche e le mamme del VI sec. d. C. Pisa: Giardini, 1970, 34. It reads, «Saluberrimus est enim conceptus? Non quidem si ingenti corporis labore et tormento perferatur» (Is pregnancy healthy? Not if it entails a great sacrifice and effort for the body). For the Hebrew, see Barkai, n. 10, p. 137 (French) and 230 (Hebrew).

31. Maimonides. On asthma. A parallel Arabic-English text. Edited, translated and annotated by Bos, Gerrit. Provo (Utah): Bringham Young University Press; 2002, p. 96.
} 
century, warned women against looking to other women for assistance with their gynaecological ailments, as they could do them much harm out of sheer ignorance ${ }^{32}$. Christian authors, too, were concerned about the medical practice of vetulae or old women ${ }^{33}$. It seems that for male authors they embody all that is negative about femininity: old age and simplicitas. Nonetheless, it seems plausible to suggest that in reality men tended to denigrate them because they were seen as competitors.

\section{Dealing with conception and pregnancy}

In general terms, what appears to be a fundamental concern among the authors of these medical texts and of other similar works preserved in any of the medieval languages, was also a core issue in the life of Jewish, Arabic and Christian communities throughout the Middle Ages: namely, fertility (and its counterpart, sterility). In the aforementioned $A$ record of the diseases occurring in the genital members, the section devoted to «feminine illnesses» starts out by addressing the problem of sterility, which it covers at length:

«On sterility and the impediments to pregnancy. The cause might be a corruption of the man's sperm or of the woman's sperm, or a malign temperament in the womb, or a hard tumor, or an ailment in the organ or a short penis» ${ }^{34}$.

As we can appreciate from this fragment, medical texts do not place all the responsibility on women, although many of the prescriptions are aimed at them. Consider, for example, the following remedy outlined in The Book of Women's Love:

«To impregnate a barren woman: He must take a hare's stomach and a fish swallowed inside another fish, and put them on a fire in a frying pan. He must pound them to a fine powder together with flour and mix this powder

32. Sefer ha-yosher, Oxford, Bodleian Library, MS Oppenheim 180 (Cat. 2134), ff. 43r, 48v y 51v. See also Caballero Navas, Carmen. The care of women's health: An experience shared by medieval Jewish and Christian women. Journal of Medieval History. 2008; 34(2): 146-163, p. 150-151.

33. Agrimi, Jole; Crisciani, Chiara. Savoir medical et antropologé religieuse. Les représentations et les fonctions de la vetula (XIII'-XIVe siècle). Annales. 1993; 5: 1281-1308.

34. Barkai, n. 2, 1998, p. 114 and 131, in Hebrew and English, respectively. 
and the flour with water. She must drink [it] in the morning and in the evening during eight days. Then, she must have intercourse and she will conceive» ${ }^{35}$.

Generally speaking, the texts only go so far as to recommend methods for discerning whether a woman (or a man, albeit to a lesser extent) is sterile, and to offer prescriptions and treatments -covering medications, special diets, aromatic substances and baths - that purport to alleviate the problem and get rid of the root cause of the infertility. Society at large, however, is less understanding of women when it comes to an infertile union. In Judaism alone, a man may seek divorce from a woman if after ten years of marriage no children have been produced ${ }^{36}$.

Although the medical texts allude to a clear relationship between menstruation and conception ${ }^{37}$, there is no agreement as to the degree to which women contribute to generation. Jewish authors largely appear to uphold a theory of Hippocratic origin, namely that of the two seeds, which explains that both men and women emit semen and thus contribute equally to creating the foetus. This belief is no doubt due to the fact that Judaism acknowledged the existence of female semen ${ }^{38}$, according to the traditional interpretation of the following Bible verse: "And the Lord spake unto Moses, saying, Speak unto the children of Israel, saying, If a woman have conceived seed (tazri'a), and born a man child: then she shall be unclean seven days; according to the days of the separation for her infirmity shall she be unclean» (Lev 12, 1-2).

As with many other Hippocratic theories, this had been adopted - and also adapted - by Galen, who considered female semen to be less perfect than male semen. This inclination to under-value the contribution of female semen to conception is further consolidated throughout the Middle Ages, particularly thanks to the triumph of Aristotelianism, as the Greek philosopher had blatantly rejected this entire theory, and had affirmed that

35. Caballero Navas, n. 3, 2004, p. 152.

36. The ruling stems from Mishnah, Yevamot 6:10. See also Salvatierra, Aurora; Ruiz Morell, Olga. La mujer en el Talmud. Una antología de textos rabínicos. Barcelona: Riopiedras; 2005, p. 81-82 and 93-94.

37. The majority of the texts include a section, or at least prescriptions, devoted to 'provoking menstrual flow', in which it is made quite explicit that menstruation is a necessary condition for a woman to get pregnant. See, for example, Caballero Navas, n. 3, 2004, p. 156-164.

38. Babylonian Talmud. Tractate Niddah 31a. 
women only contribute the matter, while men contribute the form ${ }^{39}$. The influence of Aristotle brings about a transformation in the way in which many medieval authors understand generation, and this, in turn, gives rise to a somewhat ambiguous posture on the part of many Jewish philosophers and scientists. Here the debate was between the Jewish tradition and philosophical thought. Maimonides would not deny the existence of female semen, but he entirely diminished its importance ${ }^{40}$.

That said, although the notion would make a degree of impact on Jewish intellectual circles as a philosophical idea, it would seem it did not permeate medical writings to the same extent. Almost two centuries later, the author of The treatise on procreation, written in the form of an epistle, explains to its addressee that he should not make advances to his wife while she is sleeping, as conception is only possible when the woman is sexually aroused. To this end, he recommends what he calls a «medical secret», which is to stimulate her with all manner of caresses and loving gestures ${ }^{41}$.

In line with certain medical theories, the precedence of either the man or the woman in emitting semen could determine the sex of the baby. This is a particularly important issue for medieval society and medicine that can be appreciated in the emphasis placed by texts of a scientific and not-so-scientific nature on both discovering and influencing the sex of the foetus. The explanation, based on who emits the sperm first, alternates and sometimes overlaps with another explanation that focuses on the side from which - left or right - it comes, or on which side of the uterus the foetus will become embedded. Greek philosophy relates the masculine to the right side, and the feminine to the left side - a notion that had a considerable impact on ancient and medieval philosophy and medicine. Few doctors from the Middle Ages rejected the idea that the outward aspect of one of the sides of the pregnant woman, particularly relating to the breasts, could indicate whether the baby would be a boy or a girl:

39. Aristotle. Generation of animals. Peck, Arthur, trad. Cambridge, Mass.: Harvard University Press; 1943, 729a34-730a35; Koren, Sharon Faye. Kabbalistic physiology: Isaac the Blind, Nahmanides, and Moses de Leon on menstruation. AJS Review. 2004; 28 (2): 317-339 (327).

40. Caballero Navas, n. 23, p. 74.

41. Barkai, n. 2, 1998, p. 213 and 217, in Hebrew and English, respectively. 
«Hippocrates said that if the woman begets a male, her colour is fine and her right breast is larger than the left one. If she begets a daughter, it would be the opposite» ${ }^{42}$.

Ideas on the role of laterality in determining the sex of a baby enjoyed widespread popularity, and permeated medieval ideologies in different ways. Their influence on the Kabbalah contributed to spreading the misogyny that had flourished throughout medieval thought in general during the late Middle Ages to Jewish communities, as Kabbalists developed the notion that the right represented all that was sacred, strong and masculine, while the left represented the profane, weak and feminine ${ }^{43}$.

Given the tremendous interest conveyed by these texts in bringing about pregnancies and seeing them through to a healthy outcome, it may appear contradictory that their authors should include remedies and medicines for preventing pregnancy and provoking abortions. Not only Hebrew texts but also treatises on Latin medical traditions contain to a greater or lesser extent this type of remedy, although it is difficult to judge whether this is merely a reflection of a social practice or an indicator of the scientific interests of medical authors. At least in the case of Judaism it is probable that practice would not contradict the written word, and that the innumerable contraceptive prescriptions and approaches to abortion described in the texts are an illustration of the capacity of Jewish women to control their own fertility ${ }^{44}$. This latter point would be facilitated by the fact that women were exempt from the aforementioned commandment «Be fruitful and multiply», which was the exclusive concern of men. The Babylonian Talmud includes several passages permitting the use of means for preventing pregnancy in cases where being pregnant or giving birth could endanger the life of a woman, where women are very young, or when they are already pregnant or breast-feeding ${ }^{45}$. Despite the fact that the Jewish

42. Sefer ha-seter, Hebrew translation from the Liber de sinthomatibus mulierum. Barkai, n. 2, 1998, p. 184 and 190, in Hebrew and English, respectively.

43. Koren, n. 39.

44. As affirmed by John Riddle, before this knowledge was put into the written word, they were part of the feminine knowledge tradition related to the management of daily living. Riddle, John. Contraception and abortion from the ancient world to the Renaissance. Cambridge, Mass.: Harvard University Press; 1992.

45. Babylonian Talmud, Yebamot 65b and 12b, respectively. Biale, Rahel.Women and Jewish law. The essential texts, their history, and their relevance for today. New York: Schocken Books; 1995, p. 198-218. 
way of life has at its heart the goal of procreation, the exemption of women from this obligation translated into a certain degree of permissiveness towards pregnancy-prevention and abortion. In this regard, above all there was respect for the principle of pikuah nefesh (saving a life), which gave precedence to saving the life of the mother ${ }^{46}$, thus leaving women with a degree of scope to control their own fertility.

«To prevent pregnancy: If she hangs from her neck the tongue of a deer she will not conceive all the time she is carrying it. It has the same effect as hare's excrement or its left leg hung from the neck» ${ }^{47}$.

«To abort. Take one dirhem of lodestone, pound it and give it to her to drink with absinthe liquid or with lettuce juice; it does wonders» ${ }^{48}$.

Just as with the first prescription, a good many procedures for aborting or preventing pregnancy found in Hebrew texts consist of magic. Magic is thus one of the female strategies for achieving health and well-being for themselves and their loved ones ${ }^{49}$. It is important to remember that during the Middle Ages the boundaries between magic and religion, or magic and medicine, were very blurry.

\section{The management of childbirth}

Apart from the prominence that medieval societies in general and Jewish cultures in particular ${ }^{50}$ gave to begetting children, for women of child-bearing age birth was a crucial episode in their lives, in some cases repeated several

\footnotetext{
46. Biale, n. 45, p. 219-238.

47. Caballero Navas, n. 3, 2004, p. 176.

48. Medicaments for pregnancy, called «The head's shield». Barkai, n. 2, 1998, p. 194 and 204, in Hebrew and English, respectively.

49. Caballero Navas, Carmen. Magia para curar. Amuletos, pociones y hechizos en los textos hebreos medievales dedicados a la salud femenina. In: Moreno Koch, Yolanda, Coord. De cuerpos y almas en el Judaísmo hispano medieval: entre la ciencia médica y la magia sanadora. Cuenca: Ediciones de la Universidad de Castilla-La Mancha; 2011, p. 149-168. See also Grossman, Avraham. Pious and rebellious: Jewish women in medieval Europe. Waltham, Mass.: Brandeis University Press; 2004, p. 20.

50. Although women are exempt from the divine mandate to procreate referred to above, the Jewish way of life centred around that very obligation.
} 
times over. Although it was often a common event of daily life that would unfold with total normality, it could also put women in life-threatening danger ${ }^{51}$. Both women's concerns and societal preoccupation with the risks that parturition posed for women are acknowledged in texts, which focus on three main aspects of childbirth management: birth pangs, difficult births, and post-partum ailments.

Before, during and after birth, a fundamental concern was to relieve the woman's pain and suffering. The texts reflect this concern in the prescriptions they outline to prepare the future mother by means of baths and other procedures and minimize the more troubling aspects of childbirth:

«Take gander's blood, cumin, dill and pomegranate leaves and flowers, an equal quantity of each, and make pastilles with extra fine flour. Fry them in a frying pan with gander's fat and apply them to the belly three or four times; it will relieve the pain after childbirth» ${ }^{52}$.

There is no hint in these texts of the conflict between these approaches and the Bible verse «In pain you shall bear children» (Gen. 3:16) ${ }^{53}$. Another type of literature, of moralistic nature, holds that within this divine punishment is an element for reflection. Some authors go so far as to affirm - such as Meir Aldabi, author of Shevilei emunah (Paths of Faith), an encyclopaedia concluded in Castile in 1360 - that the birth of a girl is more painful than that of a boy, as boys are born head-first and facing down ${ }^{54}$, in the direction of the dust of which Adam was created. Girls, on the other hand, are born facing up, looking up towards the rib out of which the first woman was created ${ }^{55}$.

51. According to the Mishnah, women's failure to fulfil one of the three specific feminine commandments — niddah (Laws of the menstruant), hallah (separating a portion of dough) and hadlagah (lighting candles) - would lead them to die during childbirth (Mishnah, Shabbat 2:6-7). See Klein, Michael. Obstetrics in Jewish sources. Korot. 1998-99; 13: 171-188, p. 174-175; and Ruiz Morell, Olga. Niddah: la mujer menstruante de la Ley Escrita a la Ley Oral. El Olivo. 2012; 76:21-42, p. 41.

52. Caballero Navas, n. 3, 2004, p. 172.

53. Elsakkers, Marianne. In pain you shall bear children (Gen. 3:16): Medieval prayers for a safe delivery. In: Korte, Anne-Mary, ed. Women and miracle stories: A multidisciplinary exploration. Leiden: Brill; 2001.

54. According to the treatise On the difficulties of birth, a natural birth is that in which «the head should emerge first with the face downwards, and afterwards the neck, and after that the shoulder, and it should be that his hands will be alongside the body». See note 1 .

55. Quoted by Klein, n. 51, p. 173. 
Difficulties during childbirth put the lives of the mother and her unborn child at risk, and put the expertise of midwives to the test. While the medical texts follow an androcentric discourse that portrayed the role of midwives as entirely secondary to that of the physician, they do recognize midwives' skill and competence. A record of the diseases occurring in the genital members acknowledges the midwife's expertise and autonomy when, in addressing the retention of the foetus due to its lying awkwardly, it explains that it should be she who manipulates it, guided by her «wisdom». The Hebrew word used to refer to her «wisdom», hokhmah, is the term usually employed to designate «science» in medieval philosophical and scientific texts:

«If the cause of retention [of the foetus] is abnormal presentation, you should instruct the midwife to turn it to the correct position according to her wisdom» 56 .

These texts speak of the midwife in a generic way, in terms of her occupational function. Other works regale us with examples that, albeit short on data, give us some sense of the real practice of women who had the experience and knowledge necessary to deal with difficult births. The author of the treatise Medicaments for pregnancy, called «The head's shield» showed his appreciation by recording a fumigation to assist difficult deliveries that he acknowledged to have learned from a Muslim woman ${ }^{57}$. Other texts omit the reference to who administers the remedies and only record the procedure.

Sometimes such procedures are insufficient and more aggressive strategies are called-for. The author of $A$ record of the diseases occurring in the genital members advises thus:

"If the reason is the size of the foetus, when he begins to emerge the midwife must pull him out gently after washing the area with lukewarm water, and at times with pounded saffron. She has to pull him little by little, until he is outside. If that is impossible, you should cut him [to pieces] or get him put in the way we do with a dead foetus» ${ }^{58}$.

\footnotetext{
56. Barkai, n. 2, 1998, p.117 and 136, in Hebrew and English, respectively.

57. Barkai, n. 2, 1998, p. 195 and 204, in Hebrew and English, respectively.

58. Barkai, n. 2, 1998, p. 117 and 136, in Hebrew and English, respectively. A similar procedure, no doubt outlined in the Hebrew text, can be found in Book III, Fan XXI, maqala II, cap. 28 of Avicenna's Canon of Medicine. See Meyerhoff, Max; Joannides, Dimitri. La Gynécologie et I'obstétrique chez Aviccene (Ibn Sina) et leurs rapports avec celles des grecs. Cairo: Impr. E. \&
} 
This and other procedures require the use of surgical instruments that nevertheless do not appear in texts on women's health. Once again, a document that is entirely unrelated to medicine, the Biblical Commentary on Exodus $(1,15)$ by Jacob ben Asher de Toledo, a fourteenth-century rabbi, informs us that midwives typically carried a shepoperet amongst their implements. This was a small tube used to clear the airways of babies born unconscious.

Once the baby had been born, and other women had stepped in to take care of it, the placenta had to be removed, and the birth was not considered complete until this, too, had been delivered. Failure to deliver the placenta was feared for its consequences, including the possible death of the new mother. Treatments for provoking the release of the placenta are varied. The texts recommend manual procedures carried out by the midwife, but also medicines and other methods that trigger vomiting or sneezing so as to aid expulsion. Cases in which blood or the dead foetus remained inside the woman were addressed by means of similar strategies:

«To expel and extract the placenta: Take half an ounce of live sulphur; birthwort, common centaury, myrrh and galbanum, three drachms of each, and put them over burning coals; she must receive the fumigation from below» ${ }^{59}$.

A strategy no less important to extract the placenta, or to alleviate pain, or protect the foetus and, above all, to deal with anxiety during childbirth, is to resort to magic. Medical texts are full of magical remedies and devices, and documentary sources yield evidence of magic being a widespread and acceptable healing practice in the Middle Ages, as already mentioned. Magic accompanied and guaranteed the success of healing procedures; prayers, talismans, amulets, magic squares, gems, incantations and similar resources were all part of a midwife's repertoire, as well belonging to medieval women's traditions. Magic protected women from the frailty associated with pregnancy and childbirth ${ }^{60}$.

R. Schindler; 1938, p. 46-47; and Avicena, Canūn fi at-tib. Traducción hebrea. Edición facsímil del MS 2197, Biblioteca Universitaria di Bologna. Madrid: Editorial Ars Magna; 2002, f. 387r. The practice of embryotomy was acceptable under Judaism, in virtue of the principle of pikuah. nefesh, in which saving the life of the mother takes precedent, as explained by Maimónides in his Mishneh Torah, Hilkot Rotseah 1, 9.

59. Caballero Navas, n. 3, 2004, p. 170

60. See n. 49 . 


\section{Midwives and medical practice}

As we have seen, then, the midwife held a central role in the management of childbirth, and also afterwards, as she cared for the new mother and, at times, chose and appointed the wet nurse ${ }^{61}$.

However, the label «midwife» as an occupational identity is not used in any of the medieval languages of Christian Europe (which do mention other female occupations) until the fourteenth century. By contrast, the Jewish communities that occupied those territories seem to have developed an earlier awareness of this work as a recognized occupation, as Hebrew sources record explicit mentions of meyaledet around the thirteenth century ${ }^{62}$ and even earlier, according to the dates in which some of the texts appear to have been written. The steady demand for midwives - derived from the need for healthcare during what was such a commonplace event in the lives of half the population during their child-bearing years- in all probability made it a widely-held occupation. However, the very commonplace nature of the task carried out by these women, which took place at home and was shared with female neighbours and family members, rendered it almost invisible. The commonplace is rarely named. This way of thinking appears to be present in other contexts in which practices, traditions and customs are named, and has given rise to a situation in which touchstones of Judaism such as the Mishnah, in which numerous female roles are mentioned, rarely make reference to that of the midwife ${ }^{63}$.

61. García Herrero, Maria del Carmen. Administrar el parto y recibir la criatura. Aportación al estudio de la obstetricia bajomedieval. In: García Herrero, Maria del Carmen. Del nacer y el vivir. Fragmentos para una historia de la vida en la baja Edad Media. Zaragoza: Institución Fernando el Católico; 2005, p. 21-46, p. 31.

62. Green, Monica. Bodies, gender, health and disease: Recent work on Medieval women's medicine. Studies in Medieval and Renaissance History, 3rd series. 2005; 2:1-46, p. 15-17; Green, Monica; Smail, Daniel Lord. The trial of Floreta d'Ays (1403): Jews, Christians, and obstetrics in later Medieval Marseille. Journal of Medieval History. 2008; 34(2): 185-211, p. 191; and Baumgarten, Elisheva. Mothers and children: Jewish family life in medieval Europe. Princeton: Princeton University Press; 2004, p. 43-54.

63. I am deeply indebted to Olga Ruiz Morell who drew my attention to this piece of information. In a recent publication, she has argued that, despite their interest in discussing (im)purity of postpartum bleeding, rabbis were not interested in the details of childbirth itself and, therefore, did not describe in their writings the circumstances surrounding it. See Ruiz Morell, n. 51, p. 31. 
In Jewish tradition, the midwife is given the name hayyah, a term deriving from the verb «to live» that alludes to their function of mediating with life. According to Jewish sources produced in Islamic territories, this must have been the term used in communities dotted around these regions ${ }^{64}$. As the Middle Ages unfold, and Jewish communities extend out across western Christian territories, the use of the term meyaledet becomes consolidated and repeated throughout the medical texts conserved to this day, alternating with ishah hakhamah, or «wise woman».

Certainly, some medical authors, such as the author of $A$ record of the diseases occurring in the genital members, refer to female medical practice using terms such as meyaledet (midwife), alluding to an occupational function, albeit subordinating the activity of these women to that of the physician. This means of identifying the healthcare occupation of women reveals not only the vision of male practitioners as to how female practice should be, but also a problem of nomenclature and definition. The problem became increasingly acute over time, during the process by which women were excluded from the professional categories derived from the implementation of a new medical system legitimized by universities ${ }^{65}$.

But women did not only treat other women. Despite their slow but progressive exclusion from legitimate medical practice, the healthcare needs of the population at large meant that different health systems were allowed to operate side-by-side, and women allowed to actively participate in them. We should also remember that during the Middle Ages healthcare was largely provided within the domestic sphere, which was not defined as a «healing space» but in which nevertheless women were expected to look after the healthcare needs, and treat the illnesses, of their families ${ }^{66}$.

64. As expressed by Shelomo ben Sai'ir ben Mubarak in his Jewish-Arabic biblical dictionary, produced in Fustat in the late thirteenth century-early fourteenth century. Selomo ben Mobarak. Book of facilitation, Kitâb al-Taysîr (Jewish-Arabic Dictionary of Biblical Hebrew). Edited, translated and studied by Martínez Delgado, José. Granada: Universidad de Granada; 2 vols, 2010.

65. Green, Monica. Women's healthcare in the medieval West. Aldershot: Ashgate; 2000, which includes several indispensable works -especially essays I and II- on the problems of documenting female medical practice in the medieval west.

66. Cabré i Pairet, Montserrat. Women or healers? Household practices and the categories of health care in late medieval Iberia. Bulletin of the History of Medicine. 2008; 82: 18-51; Rawcliffe, Carole. Medicine and Society in Later Medieval England. London: Sutton; 1998, p. 182-186; Anderson, Cynthia. «With her own hands»: Household instructional texts and the medieval 
The fact that the healthcare delivered by women in the domestic setting often extended beyond this context and acquired the status of an occupation is registered in diverse sources. These allude to women being granted licences to practice, notarial protocols that register occupations, royal charters, ecclesiastical documents, acts deriving from trials, funeral inscriptions, anecdotes, and other direct and indirect references ${ }^{67}$. The experience and expertise of some wise women and midwives seem to have built a significant reputation among their contemporaries, judging by the number of Jewish women who attended at the births of Christian women $^{68}$. In the context of this discussion, it is important to remember that Jewish women's medical practice was mostly recorded in connection with cross-cultural interaction and the documents it generated, such as the granting and renewal of a license. Against this backdrop, it is worth noting the Iberian use of the formal title Doña - or its dialectical form $\mathrm{Na}$ - when referring to many of these female practitioners, which denotes significant social recognition of their knowledge and skill.

To appreciate the extent of the social status implicit in the use of the address Don or Doña, we need look no further than the various different laws and regulations, such as the Castilian Ayllón Laws of 1412, which prohibited the use of such terms by Jews ${ }^{69}$. One testimony of particular interest in this regard - for it enables us to appreciate the recognition that female medical practitioners could achieve at times- are the critical words written by prominent male physicians, as alluded-to earlier ${ }^{70}$.

Regardless of what a male physician might consider «female» practice to be, gynaecology and obstetrics are two spheres of care mostly under

and Renaissance woman [doctoral thesis], Texas University; 2000, p.175-225; and Caballero Navas, n. 32.

67. Cardoner Planas, Antonio. Seis mujeres hebreas practicando la medicina en el Reino de Aragón. Sefarad. 1949; 9, p. 441-45; Shatzmiller, n. 5; Baumgarten, Elisheva. «Thus sayeth the wise midwives»: midwives and midwifery in thirteenth-century Ashkenaz. Zion. 2000; 65, p. 45-74 (Heb.); Baumgaten, n. 62; Caballero Navas, n. 32; Green; Smail, n. 62.

68. According to Montserrat Cabré, in Iberian sources, women's health practices that are identified as expert healing activities emerge in four different situations. We could categorise these Jewish women as pertaining to the third situation: «women hired by individual people or institutions to carry out specific health practices, normally during a defined period of time». See Cabré i Pairet, n. 66, p. 24-25. Attending at childbirth was not a prerogative of Jewish women. On the contrary, Christian women also attended Jewish women at childbirth.

69. Suárez Fernández, Luís. Judíos españoles en la Edad Media. Madrid: Rialp; 1980, p. 224 ff.

70. See n. 31 and 32 . 
women's control until the sixteenth century ${ }^{71}$. During the Middle Ages, in the vast majority of cases, the beginnings of life are to be found immersed in the feminine. Child-bearing women were attended to at home by female neighbours and midwives. Textual and visual sources generally show scenes populated by women, in which only exceptionally do we find a man, and not necessarily helping with delivery ${ }^{72}$. When Garsendeta gives birth in Marseilles in 1403, two midwives are in attendance, one of them Jewish, together with another six women, either neighbours or relatives, who accompany and help her ${ }^{73}$. From a revealing source from 1351 in Girona, we learn that the bishop instructs the clerics of a certain parish to absolve twelve Christian women who had been punished for helping a Jewish neighbour in labour ${ }^{74}$.

In spite of the apparent scruples regarding cross-religious interaction, and the explicit prohibitions of the Church and Jewish religious authorities, Jewish women attended to Christian women in labour and vice-versa, as in these latter examples ${ }^{75}$.

In contrast, a fragment of the aforementioned $A$ record of the diseases occurring in the genital members suggests that male physicians apparently had no access to the place were childbirth occurred. In a section where the author explains what a «mola» is (a piece of shapeless flesh that grows inside women's bodies, giving them the false impression that they are pregnant), he resorts to the testimony of «virtuous» women as a means to

71. Cabré i Pairet, n. 25, p. 640.

72. García Herrero, n. 61.

73. Green; Smail, n. 62.

74. Arxiu Diocesà de Girona, Registres de Lletres Episcopals, vol. 17 (1350-1351), fol. 190v. Quoted by Escribá i Bonastre, Gemma; Frago i Pérez, María Pilar. Documents dels jueus de Girona, 1124-1595. Girona: Ajuntament de Girona; 1992, p. 122.

75. According to Mishnah, Avodah Zarah 2, 1, «A daughter of Israel should not be a midwife to a gentile woman. But a gentile woman may be a midwife to a daughter of Israel». However, R. Shelomoh ben Abraham ben 'Adret of Barcelona (1235-1310) ruled in a responsum that a Jewish midwife could treat a gentile women for a fee. See Teshuvot ha-Rashba, I:120, The Responsa Project of Bar-llan University; and Notice $n^{\circ} 252456$, projet RELMIN, «Le statut légal des minorités religieuses dans l'espace euro-méditerranéen (Ve- XVesiècle)» Edition électronique Telma, IRHT, Institut de Recherche et d'Histoire des Textes - Orléans [accessed Jan 29, 2014\} Available from: http://www.cn-telma.fr/relmin/extrait252456/. About other Jewish and Christian attitudes regarding attention to childbirth across religious lines, see Baumgarten, Elisheva. «A separate people»? Some directions for comparative research on medieval women. Journal of Medieval History. 2008; 34 (2): 212-228, p. 220-22; and Green; Smail, n. 62, p. 192. 
support his theories on anomalous births. According to him, his trustworthy informants declared that one woman gave birth to three creatures in the shape of quadrupeds, and that another delivered a snake-like creature together with a dead foetus:

«I have been informed by some virtuous women and some midwives, without any lies and falsehoods, that one woman gave birth to three animals resembling quadrupeds; they were alive and moved $»^{76}$.

Illuminated manuscripts confirm the impression derived from written records, as they generally provide a picture of the «feminine» space in which childbirth takes place, as well as the attire, position and gestures of the pregnant woman and her attendants. The custom in the western Mediterranean, according to the existing evidence, was to sit the birthing mother on a chair, or in the lap of another woman, with the midwife sitting immediately in front, on a low seat, prepared with a cloth with which to receive the newborn ${ }^{77}$.

Bearing in mind the reputation that some midwives succeeded in creating, and the social need for their contribution to healthcare, how did these women receive the necessary training to perform this work? And what exactly was expected of them in the course of their activities? According to $A$ record of the diseases occurring in the genital members, these women had to act according to their «wisdom» (hokhmah) ${ }^{78}$ and the knowledge that they must have acquired in some way or other. Unfortunately, as is the case also in other spheres of life relating to medieval women, the sources are few and far between as regards the training they received. Literacy levels amongst women were extremely low, although they did rise from the thirteenth century onwards, perhaps above all amongst Jewish women. Even so, there are no written testimonies by Jewish women of their medical knowledge, or at least none has been identified to date. Thus we may only

\footnotetext{
76. Barkai, n. 2, 1998, p. 116 and 134, in Hebrew and English, respectively.

77. Green; Smail, n. 62, p. 195. One of the very rare medieval Jewish visual representations of childbirth, produced in Aragon in 1350, depicts Rebecca giving birth to twins Jacob and Esau. The midwife kneels in front of the birthing mother and receives both twins in her hands. While Rebecca appears to be seated, it is impossible to ascertain the shape of the birthing stool. See Haggadah of Sarajevo. Bosnia National Museum, Sarajevo, f. 9v. About the birthing stool see also n. 26.

78. See n. 56 .
} 
glimpse the way in which they acquired knowledge indirectly, by means of licences to practice or apprenticeship contracts ${ }^{79}$. The Book of generation recommends that amongst the characteristics of a good midwife is that she should be yoda'at sefer, which we might translate as «instructed in books» or «well read» ${ }^{80}$. In all that they did, whether instructed or not, Jewish women must have received their training in just the same way as men and just as any skill was learned in the Middle Ages - at the hands of another person more wise and experienced than they ${ }^{81}$. From some documents it can be gleaned that the more experienced midwives might be accompanied by other midwives, most certainly undertaking an apprenticeship, who would observe and practice under their expert eye ${ }^{82}$.

Other aptitudes and qualities that were expected of a good midwife were, according to the Book of generation and other texts of a medical and non-medical nature, that she should be well-behaved and God-fearing, be respectable, wise, intelligent, clean, honest, patient, prudent, compassionate and expert, and have wide-ranging experience ${ }^{83}$. A woman who herself had children was considered to be better equipped to attend a birth than childless women. Midwives were also expected to have certain physical characteristics, such as slim fingers and/or hands, with which to better access and manipulate the genitals of women in childbirth ${ }^{84}$.

79. For example, a document signed in Marseilles in 1326 outlines an apprenticeship contract in which the Jewess Sara de Sancto Aegidio commits to training in the art of medicine a young male apprentice, for a period of seven months. Shatzmiller, Joseph. On becoming a Jewish doctor in the High Middle Ages. Sefarad. 1983; 43: 239-250, p. 247-248.

80. Barkai, n. 10, p.129 ff.

81. Caballero Navas, n. 5, p. 320-342.

82. Caballero Navas, n. 5; García Herrero, n. 61, p. 37, which refers to the midwives who accompanied another, more expert, midwife.

83. Barkai, n. 10, p. $129 \mathrm{ff}$. Other medical texts, such as A record of the diseases occurring in the genital members, also explain the desirable qualities of midwives. See also García Herrero, n. 61, p. 30.

84. The requirement for midwives to have «slim hands and long fingers» features as a constant in the texts that have referred to them since antiquity. The Liber de sinthomatibus mulierum and its Hebrew version highlight that midwives' «small and smooth» hands are of great assistance in the management of difficult deliveries. See Caballero Navas, n. 32, p. 160-161; and García Herrero, n. 61, p. 31. 


\section{Conclusion}

The corpus of Hebrew texts on women's healthcare, which circulated amongst the Jewish communities of the Mediterranean West from the end of the twelfth century onwards, is witness to a male interest in the functioning of women's bodies that mirrors that of their Christian contemporaries. It also illustrates the effort of Jewish physicians to accommodate their medical knowledge and practice to new trends stemming from universities in order to keep up with the needs of their Christian clientele.

Although Jews participated in the medical system of the Christian milieu in which they lived, and shared many customs with their Christian neighbours, they also encountered ideas and concepts that contradicted Jewish beliefs. In these cases, the attitudes of translators, copyists, and authors of medical texts varied significantly, ranging from the adoption of concepts alien to Judaism, to their adaptation to Jewish traditions (Judaization) and their rejection and consequent elimination from texts. Although the adoption of alien notions often bears witness to processes of acculturation of the Jewish population, it also reflects the pains that Jewish practitioners took to attend to (and retain) their Christian patients. Far from being redundant, the efforts to adapt ideas and concepts embedded in texts most likely not intended for male medical practice to Christian medical trends stem from a shared interest in understanding and defining female bodies.

Along these lines, the analysis of what medical texts elaborate and record regarding fertility, pregnancy, and childbirth becomes a privileged source to understand not only how the feminine is culturally construed, but also to acquire some knowledge of the historical experience of women. On the one hand, these texts offer a glimpse of the extent to which the society that produced and consumed them was preoccupied with this sphere of care. They show, first and foremost, male interest in understanding the functioning of women's bodies and controlling their generative powers. As I have discussed in this paper, medical literature on maternity articulated the construction of meanings for female bodies and gender. However, in my view, they might also convey, even if not as their main aim, the interests of women, who, although exempted from the divine commandment of procreation, were instrumental in its fulfilment. Pregnancy and childbirth were common episodes in Jewish women's lives and, surely, many of them wished to beget children and to reach full-term pregnancies safely. 
On the other hand, medical texts also reveal information regarding women's agency in the management of childbirth. Although often indirectly, and frequently reluctantly, texts record women's health practices and their role in the management of pregnancy and childbirth, as well as in the care of women's health in general. In some occasions, they even grant authority to anonymous women's knowledge and practices. 